\title{
Mentha arvensis Flower Oil
}

National Cancer Institute

\section{Source}

National Cancer Institute. Mentha arvensis Flower Oil. NCI Thesaurus. Code C107331.

The essential oil of Mentha arvensis, the field mint. Mentha arvensis flower oil is used as a flavoring and can also be used for the treatment of skin problems. 